\title{
Immigrant integration policy and practices in Poland
}

\author{
Dorota Domalewska ${ }^{1}$, Marzena Żakowska ${ }^{1}$ \\ ${ }^{1}$ War Studies University, Poland
}

\begin{abstract}
Globalisation, open borders and population movements, especially from war torn countries, have brought a new set of opportunities and challenges to every modern state. Since its accession to the European Union in 2004, Poland has been experiencing a steady transformation from a country producing emigrants to a destination country for a growing number of immigrants. The aim of the article is to discuss the impact of immigration on policymaking at the national level with emphasis on the legal status of immigrants and integration policy issues. The article also analyses sectoral policies in areas such as the labour market, education, and welfare, pointing out the benefits offered to immigrants. The research leads to the conclusion that since the number of immigrants in Poland is significantly increasing, a comprehensive migration management system in Poland needs to be developed in order to regulate the status of immigrants, paying close attention to resolving integration policy issues.
\end{abstract}

Keywords: migration, immigrants, Poland, integration policy, policymaking, migration governance

\section{Introduction}

The analysis of migration trends in Poland has shown great dynamic in recent years. During the period when Poland was stuck behind the Iron Curtain, Poland was mainly a country that produced emigrants. In the years 1944-1989, more than 5.6 million Poles emigrated (Sakson n.d.). When Communism came

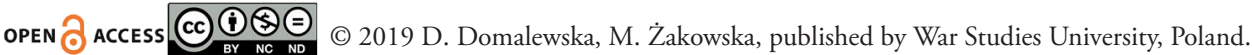
This work is licensed under the Creative Commons Attribution-NonCommercial-NoDerivatives 4.0 License. 
to an end in 1989, the decision to emigrate was motivated by economic, not political reasons. On the other hand, remigration started: in the 1990s, about 70,000 Poles returned to their homeland: 14\% from the USA and 50\% from European countries, in particular Germany (Banaszkiewicz 1999). Since joining the EU in 2004, Poland has become a preferred destination for a growing number of immigrants. In 2016, the number of immigrants outnumbered emigrants (Główny Urząd Statystyczny 2017, p. 433). The higher immigration rate results mainly from steady economic growth and changes in the labour market caused by the rapid development of some sectors as well as technology.

The purpose of the article is to outline the amount of migration in Poland and describe legislative measures aimed at improving governance of migration. In particular, we focus on immigrant integration policy. The paper is based on an analysis of legislation regulating the residence of immigrants in Poland, as well as employment, healthcare, welfare, and education access. The paper aims to initiate scientific discussion about migration integration policy and the complex system of migration policy and management.

\section{Legal status of immigrants}

A growing number of immigrants have found Poland to be their preferred destination, because of the country's steady economic growth and the inclusive policy that it pursues. However, the legal status of immigrants in Poland depends on their country of origin. If they come from a European Union member state, the legalisation of their stay, access to the labour market, education, healthcare and welfare is made simple. However, if immigrants come from a non-EU member country, their entry and stay is strictly regulated, and frequently requires a visa (Act of 12 December 2013 on foreigners). Thus, from a legal point of view, immigrants fall into 3 categories: people holding the status of long-term residents of the EU; immigrants granted refugee status or subsidiary protection; and other immigrants whose legal status is not regulated by inclusive policy and who lack access to many important social institutions (Godlewska 2013). Refugee status, according to the 1951 Convention Relating to the Status of Refugees, is granted to an individual who could face persecution in his or her country of origin "for 
reasons of race, religion, nationality, membership of a particular social group or political opinion, is outside the country of his nationality and is unable or, owing to such fear, is unwilling to avail himself of the protection of that country; or who, not having a nationality and being outside the country of his former habitual residence as a result of such events, is unable or, owing to such fear, is unwilling to return to it" (Convention and protocol relating to the status of refugees n.d.). The EU has amended directives on standards for the qualification and status of refugees and people in need of international protection. The Qualification Directive decreed in 2011 extends the reasons for which a person can apply for international protection, which include not only persecution but also war and torture. The 2011 Directive also improves the access to rights and integration measures (European Commission n.d.). Poland, as an EU member state, has established a National Contact Point for Integration, whose aim is to encourage cooperation in the field of immigrant integration policy in the EU. In Poland, refugee status and international protection is granted by the Director General of the Office for Foreigners with the consent of the Minister for Foreign Affairs. Having been granted refugee status, foreigners have the right to work without special permission. After five years, they can apply for a permanent residence permit, and after the next three years, if they meet the requirements set out in the Act on Polish Citizenship, they can be granted citizenship. However, while applying for refugee status, foreigners are not allowed to seek employment, but they may stay in centres for refugees and are entitled to medical care, maintenance, and education ${ }^{1}$. Recognition of immigrants' legal status is vital for their integration, as it determines the eligibility of immigrants not only to access healthcare, employment and welfare but also to enrol in various integration programmes.

\section{Immigrant integration policies}

The goal of Polish immigration policy is to integrate immigrants into Polish society, support their independent functioning (e.g. in the labour market), and

1 For an elaboration of the rules for granting refugee status and subsidiary protection see the Act of 13 June 2003 on granting protection to foreigners on the territory of the Republic of Poland and the Act of March 12, 2004 on social assistance. 
become welfare independent (Dragan 2016). As already mentioned, only applicants and those granted refugee status or subsidiary protection can be included in the immigrant integration programmes. Other immigrants are not eligible for integration assistance (Poland has not yet developed any introductory programmes designed to facilitate the integration of immigrants) (Godlewska 2013). Therefore, Poland does not offer any measures for immigrant labour market integration (most foreigners who are not citizens of the EU or an EEA member state are required to have a work permit). Polish law is also not flexible in granting immigrants any permits even though some regulations have been revisited. Major migration legislative changes have been made since the mid-1990s as a result of the need to unify and consolidate policies when Poland was preparing for membership and then joined the European Union. Several programmes (in 2003, 2007, and 2012) were developed in order to curb the number of undocumented migrants staying in Poland. Other legislative changes have been implemented to regulate asylum seeking, fight illegal immigration, control the local border traffic regime, and assist migration inflow to respond to changing labour market needs (Kępińska, Kindler 2013); for example, since 1 January 2017, foreigners have been more easily able to extend their stay or change job. Moreover, a number of groups of foreigners (e.g. foreigners with a permit to settle down in Poland, long-term resident permit, Polish Charter, as well as citizens of neighbouring countries but only for up to 6 months) may work in Poland without obtaining special permits, on the basis of the employer's declaration of intention to employ foreigners registered in the district labour office ${ }^{2}$.

Only certain groups of immigrants can be beneficiaries of the social security system $^{3}$ and of social assistance benefits assuming that only Polish citizens are eligible for welfare (Act of 12 March 2004 on social assistance). Table 1. below contains an overview of the social security system in Poland, its benefits and the qualifying conditions for immigrants.

2 The employment of foreigners in Poland is regulated by the Act of 20 April 2004 on the promotion of employment and labour market institutions (Journal of Laws of 2008, No. 69, item 415 , as amended).

3 The rights of foreigners to access public health care is regulated by the Act of 27 August 2004 on health care services financed from public funds (Journal of Laws of 2008, No. 164, item 1027). 
Table 1. Social security system in Poland (adapted from European Commission 2017, National Contact Point to the European Migration Network in Poland, 2014, Act of 12 March 2004 on social assistance, Act of 27 August 2004 on health care services financed from public funds, Act of 9 June 2011 on supporting the family and the foster care system)

\begin{tabular}{|c|c|c|}
\hline $\begin{array}{l}\text { Social security } \\
\text { system }\end{array}$ & Social security benefits & Qualifying criteria for immigrants \\
\hline Family & $\begin{array}{l}\text { Family allowance and supplements } \\
\text { One-off childbirth grant } \\
\text { Parental benefit } \\
\text { Benefit for bringing up a child } \\
\text { Maternity, parental and paternity } \\
\text { allowance and leave }\end{array}$ & $\begin{array}{l}\text { Family benefits are granted to all third-country } \\
\text { nationals who are covered by insurance, } \\
\text { including seasonal workers as well as the self- } \\
\text { employed. } \\
\text { Most family benefits are based on the criteria } \\
\text { of income, child age and the fact of the child } \\
\text { pursuing education. } \\
\text { Family } 500+\text { Programme is not age-dependent } \\
\text { for the second and each subsequent child. } \\
\text { Maternity, parental and paternity allowance } \\
\text { and leave are granted to people with sickness } \\
\text { insurance (compulsory for all workers) or } \\
\text { voluntary insurance. }\end{array}$ \\
\hline Health & \begin{tabular}{|l|} 
Primary healthcare \\
Specialist out-patient care \\
Hospital treatment \\
Dental treatment \\
Rescue and medical transport \\
services \\
Medicines and medical devices \\
Benefits for caregivers: \\
- Nursing benefit \\
- Special attendance allowance \\
- Caregiver allowance \\
Benefits for long-term care: \\
- Social pension \\
- Medical care allowance \\
- Medical care supplement \\
Health cash benefits: \\
- Sickness allowance and sick pay \\
- Rehabilitation benefit \\
- Compensation allowance \\
- Caregiver allowance
\end{tabular} & $\begin{array}{l}\text { Healthcare benefits are granted to every person } \\
\text { covered by health insurance and who is in } \\
\text { Poland on the basis of: } \\
\text { - a work visa, } \\
\text { - a residence permit for a fixed period except } \\
\text { for a permit granted to irregular migrants, } \\
\text { - a permit to settle, } \\
\text { - a residence permit for a long-term EU } \\
\text { resident, } \\
\text { and members of their families who are } \\
\text { registered with the National Insurance Fund } \\
\text { and who are residing in Poland. } \\
\text { Temporary migrants, residents of the EU and } \\
\text { EEA countries who are covered by health } \\
\text { insurance in their country of origin are entitled } \\
\text { to healthcare benefits in Poland. }\end{array}$ \\
\hline Incapacity & \begin{tabular}{|l|} 
Disability benefits \\
- disability pension \\
- training pension \\
Benefits that compensate accidents \\
at work and occupational \\
disease \\
- pension \\
- lump-sum compensation \\
\end{tabular} & $\begin{array}{l}\text { Disability benefits are granted to all third- } \\
\text { country nationals who have legal confirmation } \\
\text { of their incapacity for work but who have } \\
\text { worked for a specified period. } \\
\text { All insured third-country nationals who have } \\
\text { had an accident at work or an occupational } \\
\text { disease are entitled to a lump-sum } \\
\text { compensation or a pension. }\end{array}$ \\
\hline
\end{tabular}




\begin{tabular}{|c|c|c|}
\hline $\begin{array}{l}\text { Social security } \\
\text { system }\end{array}$ & Social security benefits & Qualifying criteria for immigrants \\
\hline $\begin{array}{l}\text { Old-age and } \\
\text { survivors }\end{array}$ & $\begin{array}{l}\text { Retirement pensions } \\
\text { Survivor's benefits } \\
\text { - survivor's pension } \\
\text { - funeral allowance }\end{array}$ & $\begin{array}{l}\text { All insured third-country nationals who are } \\
\text { part of a retirement scheme are entitled to } \\
\text { pensions. } \\
\text { All third-country nationals are entitled to } \\
\text { a survivor's pension if their family member } \\
\text { who had a right to a retirement pension or } \\
\text { disability pension has died. } \\
\text { A funeral allowance, which is a one-off } \\
\text { payment, is granted to any person or } \\
\text { institution who has paid funeral expenses. }\end{array}$ \\
\hline Social assistance & $\begin{array}{l}\text { Social assistance benefits } \\
\text { - permanent allowance } \\
\text { - periodic allowance } \\
\text { - earmarked allowance and the } \\
\text { special needs allowance } \\
\text { - benefit and loan for economic } \\
\text { independence } \\
\text { - assistance for becoming } \\
\text { independent and to continue } \\
\text { education }\end{array}$ & $\begin{array}{l}\text { Social assistance benefits are non-contributory; } \\
\text { they are granted to all third-country nationals } \\
\text { who: } \\
\text { - have a permit to settle } \\
\text { - have either a long-term or temporary EU- } \\
\text { resident permit }\end{array}$ \\
\hline Unemployment & $\begin{array}{l}\text { Unemployment benefits: } \\
\text { - unemployment allowance } \\
\text { - pre-retirement benefit }\end{array}$ & $\begin{array}{l}\text { Unemployment benefits can be obtained by all } \\
\text { third-country nationals who: } \\
\text { - have a permit to settle } \\
\text { - have either a long-term or temporary EU- } \\
\text { resident permit } \\
\text { and who have worked for at least } 365 \text { days } \\
\text { in the last } 18 \text { months and have earned the } \\
\text { minimum wage. }\end{array}$ \\
\hline
\end{tabular}

Immigrants whose refugee status or the status of subsidiary protection was granted in Poland are entitled to social assistance. They can stay in a centre for foreigners and receive full board, pocket money, a course in Polish, teaching aids for children, fees for taking part in extracurricular activities, and a one-off financial allowance for buying clothing and footwear. If they reside outside the centre for foreigners, they are entitled to cash benefits to cover the costs of accommodation and meals. Immigrants applying for international protection are also provided free healthcare. Other forms of help can also be granted for up to 12 months: cash benefits covering health insurance premiums, and specialist counselling (legal, psychological). They also receive support when in contact with other institutions, in particular with labour market institutions, the local community and nongovernmental organisations (https://udsc.gov.pl/trends-migration-wi-half-2017-r). 
Foreigners residing in Poland can participate in political life to a limited extent. Voting rights in municipal elections is limited to EU citizens; other foreigners are not eligible to participate in elections even if they have the status of long-term residents. However, immigrants can set up organisations but they are not eligible for public financing nor consultation procedures (Godlewska 2013).

In the education process, Poland has adopted the position of the European Union that creates equal educational opportunities to non-EU citizens regardless of their country of origin, status or other circumstances (Council Directive 2003/109/ EC of 25 November 2003 concerning the status of third-country nationals who are long-term residents). Therefore, younger children are entitled to preschool education; whereas children who are subject to compulsory education (i.e. between 7 and 16 years of age) may enroll in a primary or secondary school under the same conditions as Polish citizens, based on their place of residence. All children from immigrant families (children of immigrant workers, immigrants of Polish origin, permanent immigrants with the right to settle in Poland and permanent residence, immigrants with refugee status) attending public schools in Poland are eligible for special programmes and assistance provided by the school (Domalewska 2018). The most important goal of immigrant education is to teach Polish, because the degree of mastery of the language in which teaching is conducted determines not only academic success, but also the economic assimilation of immigrants. The inability to communicate in the target language limits the possibility of employment and affects earnings (DebBurman 2005). For this reason, the school can organise preparatory classes, in which teaching Polish and remedial teaching are combined in order to help immigrant children succeed at school. Educational policy should also teach understanding of what an armed conflict is because some migrants might have fled from a war torn country and experienced severe trauma. This experience can hamper their integration into ta new community (Żakowska 2018). At the same time, it is worth pointing out that Polish educational policies aim at creating a cooperative, friendly and safe study environment. Education entails transferring universal values, such as character, brotherhood, and respect for other cultures (Urych 2013, Trochowska, Gawlik-Kobylińska, 2015, Gawlik-Kobylińska, Trochowska, Maciejewski 2016), which can only be done by well-educated and competent teachers who strive to shape the broadly understood security of students (Urych 2012). 
Foreigners may acquire Polish citizenship administratively (recognition as a Polish citizen is granted to foreigners who, having lived in Poland for many years, have been integrated into Polish society, can speak Polish, are financially independent, obey the law, and do not pose a threat to national security). Polish citizenship may also be granted by the President of the Republic of Poland who is not bound by any conditions when considering the application ${ }^{4}$.

\section{Scale of immigration to Poland}

As has already been mentioned, the size and structure of immigration to Poland have undergone major changes in recent years. The most numerous groups of migrants in 2004 were Germans, Americans and Ukrainians (Iglicka Wejnar 2005) whereas in 2017, the inhabitants of former USSR countries dominated. According to data published by the Office for Foreigners, 89 thousand foreigners applied for a residence permit in Poland in the first half of 2017; this number increased by $42 \%$ compared to 2016 and by $87 \%$ compared to 2015 . Most of them (87\%) applied for a temporary residence permit, $11 \%$ for a permanent residence permit, while $2 \%$ of applications were submitted in order to obtain EU resident status. In addition, 5,000 EU citizens registered their stay in Poland during this period. Most applications were submitted by citizens of Ukraine (65\%), Belarus (who mostly apply for permanent residence), India (mainly applying for temporary residence), China, and Vietnam (Konieczna-Sałamatin 2015). Most frequently their reason for residence is to find employment. Immigrants often look for jobs beneath their qualifications in households, construction and logistics (https://udsc.gov.pl/ trends-migration-wi-half-2017-r). A separate group of immigrants consists of foreign students. Their number has tripled over the last 3 years and reached 65,096 foreign students in 2016/2017. They come mostly from Ukraine (half of them), Belarus (7.8\%), India (3.3\%) and other, mostly European countries (Perspektywy Education Foundation, n.d.).

4 The issue of acquiring Polish citizenship is regulated by the Act of 2 April 2009 on Polish Citizenship (Journal of Laws of 2012, item 161). 
The statistical data presented above indicates a growth in immigration to Poland. The rising number of immigrants not only stimulates economic growth but may also resolve demographic problems as a dramatic demographic shift can be seen in Poland with the population ageing as a result of long life and low fertility. Population ageing has detrimental effects not only on changes in population structure (unfavourable changes in the population of women of childbearing age as well as children and young people) but also on economic development (e.g. reduction in labour resources and an increase in the number of pensioners) (Główny Urząd Statystyczny 2014). It is estimated that by 2030, every fifth position will be vacant and approximately $8 \%$ of foreign employees would have to work in Poland in order to maintain the current level of employment (Wprost 2015).

Despite numerous advantages, a growing number of immigrants may raise security concerns. First, a growing number of illegals crossing the state border is being recorded. As Soboń and Pietruniak (2019) show, the Polish Border Guard filed 1,202 proceedings in 2016; 439 cases were related to the illegal crossing of the border, and 623 concerned using fraudulent documents at the Polish border. In 2017, the number of proceedings was 1,158; 338 cases involved an illegal crossing of the border and 298 were offences of crossing the state border with forged documents. The Polish Border Guard have also reported an increase in cross-border criminality.

Furthermore, migration has become the topic of heated debate among Poles, especially since a number of reported prejudice-motivated crimes is increasing (the hate crime rate in Poland rose from 200 in 2010 to 1548 in 2015) (Fejfer 2017). Thus, this situation has led to some antagonistic feelings between Poles and immigrants, which may affect the integration process of immigrants into Polish society (Domalewska 2016). Other difficulties experienced by immigrants that may impede the integration process include: language barrier and poor communication skills in the target language; high housing prices, which may eventually lead to homelessness; difficulties in dealing with administrative issues or institutions as well as ignorance of the possibilities offered by NGOs, institutions, and regulations (Dragan 2016). 


\section{Conclusions}

Given the high dynamics in migration movement both in Europe and globally, an increasing number of immigrants from all over the world will be coming to Poland in the nearest future. Rising immigration has been a recent phenomenon in Poland, posing a great challenge to authorities regarding developing a comprehensive approach to this problem, improving migration policy and adapting the system of migration management with the emphasis placed on immigrant integration. Changing legislation has been a challenge not only due to the increase in irregular migration in Europe but also because of the EU requirements for regulation of migration policies. At present, integration policy in Poland is directed mainly at migrants granted refugee status and applicants for subsidiary protection. As far as sectoral policies are concerned, public education is the only area that is accessible to all immigrants regardless of their country of origin, status or other circumstances. However, as the number of immigrants is expected to grow in the nearest future, the legal issues regarding immigration need to be solved and the complex system of migration policy and management should be developed.

\section{References}

Act of 12 March 2004 on social assistance (Journal of Laws of 2009 No. 182).

Act of 27 August 2004 on health care services financed from public funds (Journal of Laws of 2008, No. 164, item 1027).

Act of 9 June 2011 on supporting the family and the foster care system (Journal of Laws of 2013, item 135).

Act of 12 December 2013 on foreigners (Journal of Laws of 2013, item 1650).

Banaszkiewicz, A., 1999. Główne kierunki i natężenie migracji światowych w latach 1945-1995. In Migracje i spoteczeństwo. Warsaw, 3, 21-37.

Convention and protocol relating to the status of refugees. [online] Available from: http://www. unhcr.org/protection/basic/3b66c2aa10/convention-protocol-relating-status-refugees.html [Accessed 30 May 2018].

DebBurman, N., 2005. Immigrant education. Variations by generation, age-at-immigration, and country of origin. New York, 2005.

Domalewska, D., 2016. Immigration, stereotypes, and social security: The portrayal of migrant groups in public discourse. Security and Defence Quarterly, 13 (4), 15-31. 
Domalewska, D. 2018. Migracje a integracja imigrantów wyzwaniem edukacji dla bezpieczeństwa. In Urych, I. (ed.), Edukacja dla bezpieczeństwa. Wspótczesne kategorie. Warsaw : Wydawnictwa Akademii Sztuki Wojennej.

Dragan, A., 2016. Polska jako kraj migracji. [online] Kancelaria Senatu. Available from: https:// www.senat.gov.pl/gfx/senat/pl/senatopracowania/140/plik/ot-642_internet.pdf [Accessed 29 May 2018].

European Commission, 2017. Your social security rights in Poland. [online] Available from: http:// ec.europa.eu/social/main.jsp?catId=1124\&langId=en [Accessed 29 May 2018].

Fejfer, K. 2017. W 2016 byty o trzy przestępstwa z nienawiści mniej niż $w 2015$ i trzy razy więcej niż $w$ 2014. [online] OKO Press. Available from: https://oko.press/2016-byly-o-przestepstwanienawisci-niz-2015-razy-wiecej-niz-2014/ [Accessed 29 May 2018].

Gawlik-Kobylińska, M., Trochowska, K., and Maciejewski, P., 2016. Cywilno-wojskowe kształcenie międzykulturowe w formie blended learningu. E-mentor, 3 (65), 24-34.

Główny Urząd Statystyczny, 2017. Rocznik demograficzny 2017. Warsaw: Zakład Wydawnictw Statystycznych.

Główny Urząd Statystyczny, 2014. Sytuacja demograficzna osób starszych i konsekwencje starzenia się ludności Polski w świetle prognozy na lata 2014-2050. Warsaw: Zakład Wydawnictw Statystycznych. [online] Available from: https://udsc.gov.pl/ trends-migration-wi-half2017-r / [Accessed 21 Feb 2018].

Godlewska, J., 2013. Migracje i imigranci w Polsce - skala, podstawy prawne, polityka [online] Polski Komitet Europejskiej Sieci Przeciwdziałania Ubóstwu EAPN Polska. Available from: http://www.eapn.org.pl/wp-content/uploads/2013/07/Migracje-i-imigranci-w-Polsceskala- podstawy-prawne-polityka.pdf [Accessed 30 May 2018].

European Commission, n.d., Who qualifies for international protection [online] Available from: https://ec.europa.eu/home-affairs/what-we-do/policies/asylum/refugee-status_en [Accessed 30 May 2018].

Perspektywy Education Foundation, n.d. Over 65,000 foreign students in Poland [online] Study in Poland. Available from: http://www.studyinpoland.pl/en/index.php/news/71-over-65000-foreign-students-in-poland [Accessed 28 May 2018].

Iglicka K., Wejnar A., 2005. Wptyw rozszerzenia Unii Europejskiej na ruchy migracyjne na terenie Polski. Warsaw : Centrum Stosunków Międzynarodowych.

Kępińska E., Kindler M., 2013. Poland. In Triandafyllidou, A., Gropas, R. (eds), European immigration: sourcebook, Alershot : Ashgate.

Konieczna-Sałamatin J., 2015. Imigracja do Polski w świetle danych urzędowych. In KoniecznaSałamatin J. (ed.), Imigranci o wysokich kwalifikacjach na polskim rynku pracy. Raport z badań 2014-2015. Warsaw : Wyd. iSEE and Fundacja Nasz Wybór.

National Contact Point to the European Migration Network in Poland, 2014. Migrant access to social security in Poland. [online] Available from: https://ec.europa.eu/home-affairs/sites/ homeaffairs/files/what-we-do/networks/european_migration_network/reports/docs/emnstudies/21a_poland_national_report_social_security_en.pdf [Accessed 29 May2018].

Sakson, A. Migracje w XX Wieku. [online] Available from: http://mighealth.net/pl/images/b/b4/ Sakson.pdf [Accessed 25 May 2018].

Soboń, A., Piertuniak, M., 2019. Illegal immigration as a threat to the safety of the Republic of Poland. Security and Defence Quarterly, 23 (1), 63-78. 
Torowska, J., 2016. Sytuacja edukacyjna dzieci imigrantów w Polsce - raport Eurydice a refleksje na marginesie spotkania poświęconego aktualnej sytuacji uchodźców w Krakowie i Polsce wybrane aspekty. Prace Naukowe Akademii im. Jana Dtugosza w Częstochowie, 25.

Trochowska, K., Gawlik-Kobylińska, M., 2015. Information and communication technologies in intercultural competence training for the purpose of Ministry of National Defence. Introduction to cultural awareness course. Zeszyty Naukowe/Wyższa Szkota Oficerska Wojsk Lądowych im. gen. T. Kościuszki, 2, 79-94.

Urych, I., 2012. Autorytet nauczyciela akademickiego a odpowiedzialność. Zeszyty Naukowe AON. 86 (1), 278-290.

Urych, I., 2013. Wartości wychowania a bezpieczeństwo młodego człowieka. Zeszyty Naukowe AON. 90 (1), 227-241.

Wprost, 2015. Już w 2030 roku może brakować rąk do pracy. [online] Available from: https:// www.wprost.pl/522051/Juz-w-2030-roku-moze-brakowac-rak-do-pracy [Accessed 30 May 2018].

Żakowska M., 2018. Konflikt zbrojny jako element edukacji dla bezpieczeństwa - dylematy definicyjne. In I. Urych (ed.) Edukacja dla bezpieczeństwa. Wspótczesne kategorie. Warsaw: Akademia Sztuki Wojennej.

\section{Authors:}

Dorota Domalewska, $\mathrm{PhD}$

Faculty of National Security, War Studies University, Warsaw, Poland (iD) https://orcid.org/0000-0002-1788-1591

Marzena Żakowska, PhD

Faculty of National Security, War Studies University, Warsaw, Poland (iD) https://orcid.org/0000-0002-3245-7684 